\title{
PENGETAHUAN IBU BERHUBUNGAN DENGAN PERILAKU PENCEGAHAN DIARE PADA ANAK USIA PRESCHOOL
}

\author{
Benedictus Aditya Permana Putra ${ }^{1}$, Tuti Asrianti Utami ${ }^{2}$ \\ ${ }^{1,2}$ Sekolah Tinggi Ilmu Kesehatan Sint Carolus \\ Email : tutichaidir18@gmail.com
}

\begin{abstract}
ABSTRAK
Diare terjadi karena adanya kelainan pada fungsi pencernaan, penyerapan, dan sekresi. Peningkatan jumlah tinja dengan kadar air yang juga meningkat merupakan akibat dari adanya perubahan transportasi air dan elektrolit pada sistem gastrointestinal Penyebaran penyakit infeksi seperti diare dapat melalui tangan terutama pada anak usia preschool, sehingga perlu upaya pencegahan diare.Penelitian ini menggunakan desain cross-sectional, dengan menggunakan kuesioner. Sampel penelitian adalah ibu yang memiliki anak usia preschool sebanyak 80 responden. Uji statistik yang digunakan dengan uji kendall tau $c$. Hasil penelitian ini menunjukkan adanya hubungan pengetahuan ibu $(p=0,000)$ dengan perilaku pencegahan diare. Faktor yang melekat sebagai karakteristik ibu juga diteliti seperti usia, pendidikan dan pekerjaan ibu. Faktor tersebut tidak berhubungan dalam penelitian ini yaitu usia ibu $(p=0,813)$, pendidikan ibu $(p=0,920)$, pekerjaan $(p=0,686)$. Harapan peneliti adalah ibu-ibu di kelurahan Johar Baru selalu memiliki pengetahuan yang baik untuk melakukan pencegahan diare pada anaknya.
\end{abstract}

Kata kunci: Diare, Pengetahuan, perilaku, Preschool 


\title{
MOTHER'S KNOWLEDGE IS CONNECTED TO DIARRHEA PREVENTION BEHAVIOR IN CHILDREN AGE PRESCHOOL
}

\begin{abstract}
Diarrhea occurs due to abnormalities in digestive function, absorption, and secretion. Increasing the number of stools with increased water content is a result of changes in water and electrolyte transportation in the gastrointestinal system. The spread of infectious diseases such as diarrhea can be through the hands, especially in preschool children, so it is necessary to prevent diarrhea. This study uses a crosssectional design, using a questionnaire. The sample of the study was 80 mothers who had preschool children. Statistical tests used by the Kendall test or know c. The results of this study indicate a relationship between maternal knowledge ( $p=0,000$ with diarrhea prevention behavior. Unrelated factors in this study were maternal age ( $p=$ 0.813), maternal education ( $p=0.920)$, occupation $(p=0.686)$, researcher expectations is that mothers in Johar Baruvillage always have good knowledge to prevent diarrhea in their children.
\end{abstract}

Keywords : Diarrhea, Knowledge, Behavior, Preschool

\section{PENDAHULUAN}

Di dunia diare merupakan masalah global yang menyebabkan kematian pada anak di bawah usia 5 tahun, sekitar 1,7 milyar kasus diare pada anak khususnya balita dan menyebabkan kematian sebanyak 760.000 balita di seluruh dunia yang tiap harinya kurang lebih sekitar 1.400 anak yang meninggal karena diare(WHO, 2013; Moraga, 2016).Di tahun 2016, diare sebagai penyebab kematian nomor 8 , lebih dari 1,6 juta kematian. Lebih dari seperempat $(26 \%)$ kematian diare pada anak usia sebelum 5 tahun, dan sekitar 37\% kematian diare terjadi di Asia selatan dan Afrika (Moraga, 2016).

Di Indonesia insiden diare masih cukup tinggi, yaitu sekitar $8 \%$ pada seluruh usia, dan insiden tertinggi terjadi pada kelompok usia balita yaitu sekitar 18,5\% (Riskesdas, 2018). Di Indonesia, angka kejadian diare akut diperkirakan masih sekitar 60 juta setiap tahunnya dan angka kesakitan pada balita sekitar 200-400 kejadian dari 1000 penduduk setiap tahunnya dan 1$5 \%$ berkembang menjadi diare kronik.Jakarta Pusat memiliki presentase 9\% dari angka keseluruhan penderita diare pada balita yaitu sekitar 22 ribu penderita diare (Kemenkes, 2016)

Perilaku adalah suatu aktivitas yang dilakukan manusia itu sendiri(Notoatmodjo, 2012). Seseorang dapat menjadi sehat ataupun sakit itu tergantung pada perilaku dan kebiasaan manusia itu sendiri. Perilaku kesehatan harus diutamakan terutama oleh ibu 
yang sehari hari lebih dekat dengan anaknya. Pentingnya ibu memiliki pengetahuan yang baik mengenai kesehatan sehingga mempengaruhi perilaku ibu dalam pencegahan diare.

Intervensi terbaik untuk diare adalah melakukan pencegahan. Orang tua memerlukan informasi tentang beberapa pencegahan seperti kebersihan pribadi, perlindungan, pasokan air yang bebas kontaminasi, serta adanya persiapan makanan yang bersih. Pencegahan diare meliputi kebersihan perineum, pembuangan popok kotor, cuci tangan yang tepat, serta melakukan isolasi terhadap orang yang terinfeksi juga dapat meminimalkan penularan infeksi diare(Hockenberry, 2016).

Informasi penting yang diperlukan orang tua tentang pencegahan diare adalah, tidak memberikan obat diare dewasa kepada anak-anak, minum air yang benar-benar matang dan minuman berkarbonasi, menghindari konsumsi air keran, es, produk susu yang tidak dipasteurisasi, sayuran mentah, buahbuahan yang tidak dikupas, daging, dan makanan laut(Kasem, 2017). Pencegahan diare dapat dilakukan dengan pemberian vaksin yang dapat melindungi anak-anak dari beberapa penyakit terkait diare(Istiroha, 2016). Vaksin rotavirus diintegrasikan ke dalam program imunisasi nasional sejak tahun 2006 di Amerika Serikat, dan kemudian musim rotavirus tercatat lebih pendek, bersama dengan penurunan $46 \%$ tingkat rawat inap diare di antara anak-anak kurang dari 5 tahun(Kasem, 2017).
Anak usia pre school (4-6 tahun) berada dalam proses perkembangan, baik perkembangan nilai-nilai, fisik, kognitif, bahasa, maupun sosial dan emosional. Dalam usia pre school anak memiliki karakteristik yang berbeda dengan orang dewasa, mereka aktif, dinamis, antusias dan ingin tahu terhadap apa yang dilihat, didengar dan dirasakan. Periode ini adalah periode dimana anak sering bermain, hampir seluruh kegiatan pada usia pre school melibatkan permainan. Penyebaran penyakit infeksi dapat melalui tangan, kondisi tersebut akan berdampak terhadap tingginya kejadian infeksi pada anak khususnya infeksi yang menyebabkan diare(Sukut, 2015).

Hasil observasi pada masyarakat kelurahan Johar Baru menganggap bahwa diare merupakan penyakit yang sepele. Perilaku yang buruk sering terjadi disekitarnya seperti pembuangan limbah sampah yang sembarangan, jajan makanan yang tidak bersih, dan tidak tersedia air bersih di lingkungan sekitar, yang mana merupakan faktor penunjang terjadinya penyakit diare.. Berdasarkan uraian tersebut, maka penelitian ini mempunyai tujuan untuk mengetahui hubungan variabel pengetahuan ibu dengan perilaku pencegahan diare pada anak toddler.

\section{METODE PENELITIAN}

Penelitian ini dilakukan dengan menggunakan metode kuantitatif dengan desain penelitian uji korelasional deskriptif dan cross sectional (Polit, 2012). Penelitian ini dilakukan di Posyandu RW 01 
Kelurahan Johar Baru Jakarta Pusat yang memiliki 97 kasus diare pada anak usia dibawah 10 tahun pada bulan Agustus 2018. Populasinya adalah ibu yang memiliki anak usia preschool yang datang ke Pelayanan Kesehatan di Posyandu RW 01 Kelurahan Johar Baru sebanyak 98 ibu. Pengambilan sampel dilakukan dengan simple randomdan menggunakan Tabel Krejciesebanyak 80 ibu yang mempunyai anak usia preschool, pada bulan Juni-Juli 2019. Kuesioner pernyataan pengetahuan dan perilaku dalam penelitian ini berupa angket dengan menggunakan skala Gutman, tujuannya agar mendapat jawaban yang tegas terhadap suatu pernyataan yang ditanyakan.

Peneliti telah melakukan uji validitas kepada 30 ibu. Uji kuesioner ini dilakukan pada ibu dari anak usia preschool yang berada di Posyandu RW 01 Kelurahan Johar Baru.Dari 17 pernyataan, terdapat 11 pernyataan tentang pengetahuan ibu terhadap pencegahan diare pada anak usia preschool yang valid dan dari 17 pernyataan, terdapat 9 pernyataan tentang perilaku ibu terhadap pencegahan diare pada anak usia preschool yang valid. Total nilai validitas dan reliabilitas dengan Cronbach's Alpha 0.669 dan nilai r sebesar 0,360 .

Peneliti memperhatikan prinsipprinsip etik untuk melindungi hak responden selama penelitian dengan mempertimbangkan the five right of human subjects in research yaitu (respect for autonomy) responden diberikan kebebasan untuk bersedia atau menolak setelah mendapat penjelasan dari peneliti, (privacy atau dignity) responden memiliki hak untuk dihargai, responden bersedia menandatangani informed consent, nama responden menggunakan nama insial (anonymity), (confidentiality) merahasiakan informasi yang telah diberikan oleh responden (Polit, 2012).

Analisis data yang dilakukan adalah analisa univariat untuk mendapatkan data frekuensi pengetahuan dan karakteristik responden dan analisis bivariat dengan uji chi square dan kendall's tau $b$ untuk melihat hubungan antara pengetahuan, usia, pendidikan dan pekerjaan. Pada tingkat significant 95\% dengan 0,05 (jika $\mathrm{p}$ value $<0.05$ maka artinya ada hubungan bermakna antar variable dan sebaliknya).

\section{HASIL PENELITIAN}

Tabel 1. Distribusi frekuensi

\begin{tabular}{lccc}
\hline Kategori & Frekuensi (f) & $\begin{array}{c}\text { Persentasi } \\
(\boldsymbol{\%})\end{array}$ \\
\hline Usia Responden & $<$ median (31,5 tahun) & 40 & 50 \\
& $\geq$ median (31,5 tahun) & $\mathbf{4 0}$ & $\mathbf{5 0}$
\end{tabular}




\begin{tabular}{llcc}
\hline & 41-56 tahun & 4 & 7.5 \\
\hline \multirow{2}{*}{ Pendidikan } & Menar (SD) & 6 & 7,5 \\
& SMA) & & \\
& Tinggi (D3-S2) & $\mathbf{6 0}$ & $\mathbf{7 5 , 0}$ \\
& Bekerja & 14 & 17,5 \\
Pekerjaan & Ibu Rumah Tangga & 57 & 28,7 \\
& Baik & $\mathbf{2 8}$ & 71,3 \\
Pengetahuan & Cukup & 26 & 32,5 \\
& Kurang & 26 & 32,5 \\
\hline \multirow{2}{*}{ Perilaku } & Baik & 53 & 66,3 \\
& Buruk & $\mathbf{2 7}$ & $\mathbf{3 3 , 8}$ \\
\hline
\end{tabular}

Tabel 1 menjelaskan bahwa ibu yang memiliki anak preschool datang ke posyandu sebanyak 80 responden diperoleh data terbanyak pada usia dibawah 31,5 tahun sebanyak 40 (50\%) ibu, responden berpendidikan menengah (SMP-SMA) sebanyak 60 (75\%)ibu, dan pekerjaan sebagai ibu rumah tangga sebanyak 57 ibu (71.3\%), pengetahuan baik sebanyak28 (35\%) dan perilaku pencegahan diare yang benar sebanyak $53(66,3 \%)$ ibu.

Tabel 2. Hubungan antara usia, pendidikan, pekerjaan dan pengetahuan terhadap perilaku ibu untuk pencegahan diare pada anak Preschool

\begin{tabular}{|c|c|c|c|c|c|c|c|}
\hline \multirow{3}{*}{ Usia } & \multicolumn{4}{|c|}{$\begin{array}{c}\text { Perilaku ibu untuk pencegahan } \\
\text { diare pada anak Preschool }\end{array}$} & \multirow{2}{*}{\multicolumn{2}{|c|}{ Total }} & \multirow{3}{*}{$\begin{array}{c}\text { Nilai } \\
\mathrm{P}\end{array}$} \\
\hline & \multicolumn{2}{|c|}{ Baik } & \multicolumn{2}{|c|}{ Buruk } & & & \\
\hline & $\mathrm{N}$ & $\%$ & $\mathrm{~N}$ & $\%$ & $\mathrm{~N}$ & $\%$ & \\
\hline \multicolumn{8}{|l|}{ Usia } \\
\hline$<31,5$ tahun & 27 & 67,5 & 13 & 32,5 & 40 & 100 & 0,813 \\
\hline$\geq 31,5$ tahun & 26 & 65 & 14 & 35 & 40 & 100 & \\
\hline \multicolumn{8}{|l|}{ Pendidikan } \\
\hline Dasar & 5 & 83,3 & 1 & 16,7 & 6 & 100 & \\
\hline Menengah & 38 & 63,3 & 22 & 36,7 & 60 & 100 & 0,920 \\
\hline
\end{tabular}




\begin{tabular}{lccccccc} 
Tinggi & 10 & 71,4 & 4 & 28,6 & 14 & 100 & \\
\hline $\begin{array}{l}\text { Pekerjaan } \\
\quad \text { Bekerja }\end{array}$ & 16 & 69,6 & 7 & 30,4 & 23 & 100 & 0,686 \\
IRT & $\mathbf{3 7}$ & $\mathbf{6 4 , 9}$ & 20 & 35,1 & 57 & 100 & \\
\hline $\begin{array}{l}\text { Pengetahuan } \\
\text { Baik }\end{array}$ & $\mathbf{2 8}$ & $\mathbf{1 0 0}$ & $\mathbf{0}$ & $\mathbf{0}$ & 28 & 100 & \\
Cukup & 16 & 61,5 & 10 & 38,5 & 26 & 100 & 0,000 \\
Kurang & 9 & 34,6 & 17 & 65,4 & 26 & 100 & \\
\hline
\end{tabular}

Tabel 2 menjelaskan bahwa ibu dengan usia kurang dari 31,5 tahun sebanyak 27 (67,5\%), pendidikan menengah (SMP-SMA) sebanyak 38 $(63,3 \%)$, pekerjaan sebagai ibu rumah tangga sebanyak $37(64,9)$ dan dengan pengetahuan baik sebanyak 28 (100\%) yang memiliki perilaku baik untuk pencegahan diare pada anak preschool.

Hasil ujikendall tau diperoleh bahwa tidak ada hubungan antara usia dengan perilaku ibu(p value $=0,813)$, tidak ada hubungan antara pendidikan

\section{PEMBAHASAN PENELITIAN}

\section{a. Hubungan usia ibu dengan perilaku pencegahan diare pada anak usia preschool}

Usia merupakan tahapan

kronologikal dalam periode kehidupan manusia yang berbeda. Semakin bertambahnya umur seseorang makin banyak pula pengetahuan yang ia dapatkan (Notoatmodjo, 2012). Usia merupakan faktor individu dimana semakin bertambah usia seseorang, maka akan semakin bertambah kedewasaan dan semakin banyak menyerap informasi. Pertambahan usia dengan perilaku ibu ( $\mathrm{p}$ value $=0,920)$, tidak ada hubungan antara pekerjaan dengan perilaku ibu ( $\mathrm{p}$ value $=0,686$ ) dan adanya hubungan antara pengetahuan dengan perilaku ibu ( $p$ value $=0,000$ ) dalam pencegahan diare pada anak usia preschool di Posyandu Kelurahan Johar Baru.

Abdinia, B. (2014). Knowledge and practice of mothers in the management of children's Diarrhea, in Northwest, Iran. Arch Pediatr, 2(4), e17581.

juga akan menumbuhkan kapasitas pribadi seseorang dalam mengatasi suatu persoalan.Usia ibu adalah faktor signifikan (prediktor) untuk pengetahuan mereka tentang pencegahan dan pengelolaan diare. Kategori yang lebih tua yaitu 30-39 tahun lebih banyak memiliki pengetahuan tentang pencegahan diare yang baik dibandingkan dengan kategori referensi ( $\leq 19$ tahun), dan ini mungkin karena fakta bahwa ibu yang lebih tua mungkin tidak memiliki akses ke pendidikan formal, tidak seperti yang lebih muda. Dapat disimpulkan bahwa 
ibu dengan usia 30-39 tahun memiliki lebih banyak pengalaman dan pengetahuan sebelumnya dan pemahaman tentang pencegahan diare (Adeleke, 2019).

Penelitian Novrianda, Yeni, dan Asterina (2014) menjelaskan bahwa terdapat hubungan bermakna antara usia responden dengan pengetahuan tentang penatalaksanaan diare pada balita $(\mathrm{p}<$ 0,05), karena kecenderungan peningkatan pengetahuan tentang penatalaksanaan diare pada balita pada kelompok umur yang tua. Rata-rata responden kelompok umur tua memiliki 2 hingga 3 orang anak dan tentunya memiliki pengetahuan dan pengalaman lebih baik dalam merawat anak terutama penatalaksanaan diare dibandingkan responden dengan kelompok umur muda yang baru mempunyai 1 orang anak.

Pengetahuan ibu yang sedang dikarenakan rata-rata pendidikan ibu adalah SMA, sebagian besar berusia diatas 30 tahun dengan usia terendah 20 tahun dan usia tertinggi 44 tahun. Orang yang mempunyai usianya matang dan berpendidikan tinggi biasanya mempunyai wawasan yang luas tentang pencegahan diare (Rane, 2017).

Penelitian Abidinia, tahun 2014 dengan judul Knowledge and Practice of Mothers in the Management of Children's Diarrhea, in Northwest, Iran menjelaskan bahwa Tidak ada hubungan antara usia ibu yang diamati dengan pengetahuan dan perilaku ibu $(\mathrm{P}=0,36)$, karena perilaku ibu yang buruk bukan disebabkan karena usia ibu. Tetapi karena dalam memberikan pelayanan kesehatan, tenaga kesehatan seperti dokter, perawat dan staf layanan kesehatan lainnya tidak memberikan informasi atau pengetahuan tentang ketrampilan yang diperlukan untuk merawat anaknya dengan diare seperti mempromosikan penggunaan lebih banyak cairan, melanjutkan melanjutkan menyusui, memberikan nutrisi yang tepat, dan merawat anak-anak selama periode diare sampai dengan sehat (Abdinia, 2014)

Menurut peneliti, berapa pun umur ibu, jika pengalaman dalam perawatan kesehatan anak lebih banyak maka perilaku pencegahan diare dapat dilakukan tergantung pendidikan dan pengalaman ibu.

\section{b. Hubungan pendidikan ibu dengan perilaku pencegahan diare pada anak usia preschool}

Penelitian ini tidak sejalan dengan penelitian Febrianti dan Anggraini (2018), dimana uji statistik dapat dilihat, bahwa antara tingkat pendidikan ibu dan perilaku ibu dalam perawatan diare, didapatkan p-value $=0,005$, berarti ada hubungan yang signifikan antara pendidikan dengan prilaku ibu terhadap perawatan diare.Dalam penelitian Febrianti dan Anggraini (2018), mayoritas responden hanya tamatan SMP-SMA, sehingga dimaklumi kalau tingkat pengetahuan yang mereka peroleh masih minim.

Pendidikan ibu merupakan salah satu kunci perubahan sosial budaya(Febrianti, 2019). Pendidikan yang relatif tinggi akan memiliki perilaku yang lebih baik terhadap pemeliharaan kesehatan keluarga terutama pada anak balita. Penelitian ini 
menjelaskan bahwa ada hubungan bermakna antara pendidikan dengan perilaku ibu terhadap perawatan kulit balita dengan diare ( $\mathrm{p}$ value $=0,005)$, berarti semakin tinggi tingkat pendidikan ibu maka semakin baik perilaku perawatan ibu pada balita yang mengalami diare (Febrianti, 2019).

Penelitian Riyanto tahun 2013 menjelaskan bahwa seseorang yang berpendidikan rendah tidak berarti mutlak berpengetahuan rendah, karena pengetahuan tidak mutlak diperoleh dari pendidikan formal tetapi dapat juga dari pendidikan non formal. Jika seseorang mempunyai pengetahuan yang positif tentang suatu objek maka akan menumbuhkan sikap dan perilaku yang makin positip dari objek yang diketahuinya.

Program pemerintah untuk memajukan pendidikan ibu dapat dilakukan dengan mengadakan berbagai kegiatan dalam bentuk promosi kesehatan. Promosi kesehatan adalah upaya untuk memotivasi, mendorong dan membangkitkan kesadaran akan potensi yang dimiliki masyarakat sehingga akhirnya mampu memelihara dan meningkatkan kesehatan dirinya (Pender, 2011). Pengaruh promosi kesehatan dapat meningkatkan pengetahuan $(\mathrm{p}$ value $=0,000)$ dan dengan peningkatan pengetahuan dapat meningkatkan kepatuhan pasien dalam pengobatan (Utami T. A., 2017).

Menurut peneliti, faktor pendidikan merupakan unsur yang sangat penting karena pendidikan seseorang dapat menerima lebih banyak informasi terutama dalam menjaga kesehatan diri dan keluarga dan memperluas cakrawala berpikir sehingga lebih mudah mengembangkan diri dalam mencegah terjangkitnya suatu penyakit dan memperoleh perawatan medis yang kompeten. Maka dari itu, ibu yang memiliki pendidikan tinggi atau rendah tidak berhubungan dengan cara ibu melakukan pencegahan diare pada anak.

\section{c. Hubungan pekerjaan ibu dengan perilaku pencegahan diare pada anak usia preschool.}

Penelitian ini tidak sejalan dengan, Adeleke dan Mhlaba (2019) yang berjudul "Pengetahuan, sikap dan praktik maternal pencegahan dan manajemen diare pada anak di Urban dan Rural Maseru, Lesotho" dimana uji statistik dapat dilihat, bahwa antara status pekerjaan dengan pencegahan diare memiliki $\mathrm{p}$-value $=0.04$. Hal ini disebabkan karena ibu rumah tangga lebih ++banyak memiliki pengetahuan yang baik di banding dengan ibu yang bekerja. Ini mungkin disebabkan oleh waktu ibu yang selalu dengan anaknya, sehingga perrhatian ibu terhadap anak tidak terbagi dengan pekerjaan.

Pendapatan atau penghasilan yang rendah dengan status ekonomi negara yang miskin akan memperkuat keadaan rumah tangga yang miskin karena kurangnya lapangan pekerjaan dan kurangnya pendidikan ibu. Tetapi keadaan ini tidak menyebabkan kesehatan anak-anaknya bergantung pada status ekonomi. Beberapa faktor penentu status kesehatan anak adalah status imunisasi dan pendidikan ibu, sehingga ibu-ibu dengan kondisi 
perekonomian yang kurang harus menerima program khusus untuk mencegah penyakit diare pada anaknya (Pinzón-Rondón, 2015).

Menurut peneliti, berbagai informasi kesehatan yang ditayangkan oleh media televisi dapat disaksikan oleh ibu-ibu sambil memperhatikan anak-anaknya. Begitu pula halnya dengan responden yang bekerja, walaupun waktu mereka akan terbagi antara pekerjaan dan merawat anak, mereka tetap harus lebih dulu mengurus keluarga terutama anak-anak. Dengan bekerja tentunya akan terjalin hubungan-hubungan sosial dengan rekan kerja sehingga dengan sendirinya akan menambah wawasan dan memberikan sudut pandang yang beragam. Bagi ibu-ibu yang bekerja tetap dapat menikmati pekerjaan mereka, karena melalui pekerjaan tersebut mereka bisa menambah pengetahuan khususnya cara untuk mencegah diare pada anak.

\section{d. Hubungan pengetahuan ibu dengan perilaku pencegahan diare pada anak usia preschool.}

Pencegahan diare pada anak, sangat dipengaruhi oleh pengetahuan ibu, sehingga dengan pengetahuan ibu yang baik diharapkan tidak menimbulkan dampak kesehatan lainnya dari diare, hal ini menunjukkan bahwa pengetahuan ibu yang kurang tentang pencegahan diare sebagai faktor utama yang menyebabkan terjadinya diare pada anak (RKW, 2012). Penelitian ini menunjukkan jika ibu mengetahui bahwa sebaiknya ibu memasak makanan dan minuman balitanya sendiri, lingkungan yang tidak sehat seperti sumber air yang terlalu dekat dengan septictank dan lingkungan yang kumuh dan kotor dapat berpengaruh terhadap kesehatan balita terhadap penyakit diare. Selain itu sebagian besar ibu juga mengetahui bahwa balita yang menderita diare maka pemberian ASI sebaiknya dilanjutkan dan tidak boleh makanmakanan berserat karena peristaltic usus akan bekerja lebih berat.

Penelitian ini sejalan dengan Dwiastuti, Sabban, dan Fitri (2018) menunjukkan bahwa adanya hubungan antara peningkatan pengetahuan dengan perilaku pencegahan diare pada balita ( $\mathrm{p}$-value $=0,045)$. Berdasarkan data yang diperoleh melalui wawancara, responden dengan kelompok ibu-ibu yang memiliki usia lebih tua ternyata rata-rata mempunyai 2 hingga 3 orang anak, sehingga mereka lebih berpengalaman dan mengetahui dengan baik dalam merawat anak terutama penatalaksanaan diare, daripada responden dengan kelompok umur muda yang rata-rata baru memiliki 1 orang anak.

Penelitian ini menunjukkan sebagian besar ibu memiliki perilaku baik tentang pencegahan diare pada anak usia pre school diketahui dari pernyataan perilaku ibu ketika menjawab dengan benar. Seperti ibu sebaiknya tidak membiarkan anak jajan di sembarang tempat untuk mengurangi resiko diare, mencuci tangan sebelum makan sebagai langkah awal pencegahan diare, membiarkan sampah menumpuk dan kotor di dapur tidak menyebabkan diare, mengkonsumsi 
makanan dan minuman yang benarbenar matang dapat meminimalisir resiko diare pada anak,

Menurut peneliti, pengetahuan ibu sangat berpengaruh dalam perilaku pencegahan diare, dimana ibu yang memiliki pengetahuan baik akan mengerti cara melakukan pencegahan terhadap diare, sementara ibu yang memiliki pengetahuan yang kurang, memiliki perilaku pencegahan yang kurang, hal ini dikarenakan ibu yang memiliki pengetahuan baik selalu mencari tahu hal-hal atau informasi yang baik tentang cara memenuhi kebutuhan kesehatan, terutama dalam hal pencegahan diare pada anak usia preschool. Untuk itu penting diselenggarakan pendidikan dan promosi kesehatan karena dapat meningkatkan pengetahuan dan mengubah perilaku (Notoatmodjo S. , 2012; Utami, 2017) Salah satu pengetahuan yang perlu disampaikan adalah faktor yang dapat meningkatkan terjadinya diaremisalnya faktor lingkungan, praktik-praktik higienis ketika menyiapkan makanan dengan tangan yang belum dicuci, membersihkan tinja seorang anak, membiarkan anak bermain ditempat yang kotor, mengajarkan ibu cara pngolahan dan penyiapan makanan (Susanti, 2017).

\section{KESIMPULAN DAN SARAN}

Berdasarkan hasil penelitian yang telah dilakukan, dapat disimpulkan bahwa pengetahuan ibumemiliki hubungan dengan perilaku ibu dalam pencegahan diare pada anak usia preschool di Posyandu RW 01
Kelurahan Johar Baru. Walaupun sebagian besar ibu dengan pendidikan menengah (SMP-SMA) tetapi mereka memiliki lebih banyak pengetahuan yang baik sehingga mampu menerima dan mencari lebih banyak informasi terutama dalam perilaku mencegah anaknya yang usia preschool dan keluarga dan memperluas cakrawala berpikir sehingga lebih mudah mengembangkan diri dalam mencegah terjangkitnya suatu penyakit dan memperoleh perawatan medis yang kompeten.

Peneliti mengharapkan Posyandu RW 01 Kelurahan Johar Baru dapat meningkatkan pemberian promosi kesehatan kepada seluruh ibu-ibu terkait pencegahan diare, agar pengetahuan ibu lebih meningkat dan dapat mencegah serta meminimalisir terjadinya diare. Selain itu peneliti juga berharap edukasi pencegahan diare dapat diterima oleh semua kalangan ibu di Posyandu RW 01 Kelurahan Johar Baru.Saran untuk penelitian selanjutnyauntuk mencari variabel lain dengan jumlah sample lebih banyak dengan memberikan implikasi promosi kesehatan.

\section{UCAPAN TERIMAKASIH}

Peneliti mengucapkan terimakasih kepada Kelurahan Johar Baru dan STIK Sint Carolus yang telah memberikan kesempatan dan kepercayaan sehingga penelitian ini dapat diselesaikan dengan baik. Semoga hasil penelitian dapat digunakan sebaik baiknya utk pengembangan pelayanan kesehatan. 


\section{DAFTAR PUSTAKA}

Abdinia, B. (2014). Knowledge and practice of mothers in the management of children's Diarrhea, in Northwest, Iran. Arch Pediatric , 2(4), e17581.

Adeleke, A. I. (2019). Maternal Knowledge, Attitudes and Practices towards Prevention and Management of Child Diarrhoea in Urban and Rural Maseru, Lesotho. International Journal of TROPICAL DISEASE \& Health, 120.

Dwiastuti, A. S. (2018). Faktor-faktor yang berhubungan dengan upaya ibu dalam melakukan pencegahan diare pada balita di desa Kamal wilayah kerja puskesmas Kairatu Barat. . Global Health Science (GHS) , 3(3), 259-266.

Febrianti, A. \&. (2019). Hubungan pendidikan dan prilaku ibu terhadap perawatan kulit pada anak umur 0-3 tahun yang menderita diare di wilayah kerja puskesmas pemulutan kabupaten Ogan Ilir. . Seminar Nasional Keperawatan , No. 2, pp. 12-17.

Hockenberry, M. J. (2016). Wong's Nursing Care of Infants and Children (10th ed.). Canada: Elseiver Mosby.

Istiroha, I. \&. (2016). Perilaku Hidup Bersih Dan Sehat (Phbs) Ibu Berhubungan Dengan Kejadian Diare Pada Balita (Mother Hygienic and Healthy Behavior Assosiated with the Incident of Infant Diarrhea). Journals of Ners Community , 7(2), 201-207.

Kasem, A. O. (2017). Assessment the knowledge of mothers regarding
Diarrhea of Children less than five years at Internally Displaced Persons (IDPs) Arbit camp: A descriptive study. Kurdistan Journal of Applied Research, 2(1), 31-38.

Kemenkes. (2016). Profil kesehatan Indonesia tahun 2017. Jakarta: Kementerian Kesehatan Indonesia.

Moraga, P. \&. (2016). Causes of Death Collaborators. 2017 Global, regional, and national age-sex specific mortality for 264 causes of death, 1980-2016: a systematic analysis for the Global Burden of Disease Study 2016. . The Lancet, 390(10100), 1151-121.

Nelson. (2014). Ilmu Kesehatan Anak Esensial (6 ed.). (K. J. Marcdante, R. M. Kliegman, H. B. Jenson, \& R. E. Behrman, Eds.). Singapura: Elsevier.

Notoatmodjo. (2012). Ilmu Perilaku Kesehatan. Jakarta: Rineka Cipta.

Notoatmodjo, S. (2014). Metodologi Penelitian Kesehatan. Jakarta: Rineka Cipta.

Notoatmodjo, S. (2012). Promosi Kesehatan Dan Perilaku Kesehatan. Jakarta: Rineka Cipta.

Novrianda, D. \&. (2014). Hubungan Karakteristik Ibu dengan Pengetahuan tentang Penatalaksanaan Diare pada Balita. NERS Jurnal Keperawatan , 10(2), 159-165.

Pender, N. J. (2011). Health promotion in nursing practice. Boston: Pearson.

Pinzón-Rondón, Á. M.-A.-M.-S.-v.-M. (2015). Country characteristics and 
acute diarrhea in children from developing nations: a multilevel study. . BMC Public Health , 15(1), 811.

Polit, D. F. (2012). Nursing Research : Generating And Assesing Evidence For Nursing Practice. Philippines: Lippincott Williams and Wilkins.

Rane, S. J. (2017). Hubungan Tingkat Pengetahuan Ibu Tentang Diare Dengan Kejadian Diare Akut pada Balita di Kelurahan Lubuk Buaya Wilayah Kerja Puskesmas Lubuk Buaya Padang Tahun 2013. . Jurnal Kesehatan Andalas, 6(2), 391-395.

Riskesdas. (2018). Hasil Utama Riskesdas $2018 \quad$ Kementerian Kesehatan. Jakarta: Badan Penelitian dan Pengembangan Kesehatan.

Riskesdas. (2013). Profil Kesehatan Indonesia Tahun 2013. Jakarta: Kementerian Kesehatan RI.

Riyanto, B. A. (2013). Kapita selekta kuisioner pengetahuan dan sikap dalam penelitian kesehatan. Jakarta: Salemba Medika.

RKW, N. P. (2012). Hubungan antara Perilaku Ibu dan Kejadian Diare pada Bayi di Wilayah Kerja Puskesmas
Siantan Hilir. Jurnal Mahasiswa PSPD FK Universitas Tanjungpura, 1(1).

Sukut, S. S. (2015). Faktor kejadian diare pada balita dengan pendekatan teori Nola J. Pender di IGD RSUD Ruteng. . Jurnal Pediomaternal , 3(2), 230-249.

Susanti, E. \&. (2017). Hubungan pengetahuan ibu tentang hygiene makanan dengan kejadian diare pada bayi di wilayah kerja posyandu melati kelurahan tlogomas malang. . Nursing News: Jurnal Ilmiah Keperawatan, 2(1), 174-180.

Utami, T. A. (2017). Promosi Kesehatan Nola Pender Berpengaruh Terhadap Pengetahuan dan Kepatuhan ODHA Minum ARV. . Jurnal Ners dan Kebidanan Indonesia , 5(1), 58-67.

Utami, T. A. (2017). Promosi Kesehatan Nola Pender Berpengaruh Terhadap Pengetahuan dan Kepatuhan ODHA Minum ARV. Jurnal Ners dan Kebidanan Indonesia , 5(1), 58-67.

WHO. (2013). Guideline for The Management of Common Chilhood Illnesses Second Edition. Switzerland: World Health Organization. 